\title{
Migrant Publics: Mass Media and Stranger- Relationality in Urban Space
}

Les publics migrants : medias de masse et relations d'altérité dans l'espace urbain

Públicos migrantes: los medios de comunicación de masas y la relación al Otro en el espacio urbano

\section{Kira Kosnick}

\section{(Q) OpenEdition}

\section{Journals}

Electronic version

URL: https://journals.openedition.org/remi/5030

DOI: $10.4000 /$ remi.5030

ISSN: $1777-5418$

\section{Publisher}

Université de Poitiers

\section{Printed version}

Date of publication: 1 February 2010

Number of pages: $37-55$

ISBN: 978-2-911627-54-5

ISSN: 0765-0752

\section{Electronic reference}

Kira Kosnick, "Migrant Publics: Mass Media and Stranger-Relationality in Urban Space", Revue européenne des migrations internationales [Online], vol. 26 - n¹ | 2010, Online since 01 February 2013, connection on 15 April 2022. URL: http://journals.openedition.org/remi/5030 ; DOI: https://doi.org/ 10.4000/remi.5030 


\title{
Migrant Publics: Mass Media and Stranger-Relationality in Urban Space
}

\author{
Kira KOSNICK*
}

\section{INTRODUCTION}

On the evening of June $26^{\text {th }}, 2007$, the city of Berlin was in the grips of serious football fever. Scores of young men and, to a lesser extent, women had taken to the streets after the final whistle of a cup final to celebrate their winning team. The German Football Association Cup final game is traditionally played out in Berlin. On the Kurfürstendamm, the centre high street of what was formerly West Berlin, hornhonking car corsos with passengers waving flags were applauded by the crowd, many of them clad in the red and black colours of the new cup final champions, 1 . FC Nürnberg. These scenes of triumphant celebration were mirrored in the district of Kreuzberg, home to one of the largest populations of Turkish nationals outside of Turkey. What was different was the colour of the flags and shirts - yellow and blue, not red and black. In Kreuzberg, scores of young people with migrant backgrounds from Turkey were celebrating not the new German cup final champions but rather club Fenerbahçe's decisive win of the Turkish Süper Lig that very same night in Istanbul. Late into the night, they chanted slogans and cheered each other on as they drove or walked up and down the main streets of the district most closely associated with Turkish life in the city.

What transpired that night in different parts of Berlin provides a good indication for what is at stake when thinking about the contemporary relationship between media, ethnic minorities and the public sphere. The simultaneity of public celebrations in the city, occasioned by two football matches and national title decisions in two different nation-states, tells us something about both the existence of transnationally mass-mediated public spheres and the ways in which ethnic minorities and

* Junior Professor of Cultural Anthropology and European Ethnology, Goethe University Frankfurt, Senckenberganlage 31-33, 60054 Frankfurt, Germany - kosnick@em.uni-frankfurt.de 
(post)migrants ${ }^{1}$ can lay claim to and contribute to public space in urban environments. It is the connection between minority media and the construction of virtual and nonvirtual urban publics which interests me here in this article. In order to make this connection, it will be necessary to revisit the concept of the public sphere as it has been discussed in relation to media audiences and producers, and suggest a wider sense of the concept of the public that will allow me to address dimensions of publicness that tie it back to non-virtual urban spaces. Retracing the development and recent transformations of Turkish minority media in Germany, I will discuss the factors that account for the apparent decline of multicultural broadcasting in the country and examine how the reconfiguration of Turkish-language mass media potentially affects claims for minority representation and urban space-making.

The concept of the public sphere has for a long time held a prominent place in minority and migrant media discussions (Becker, 1998; Fraser, 1992; Georgiou, 2006; Husband, 1994; Kosnick, 2007; Riggins, 1992; Rigoni, 2002; Sreberny, 2001; Siapera, 2005), highlighting the importance of (mass) media as arenas of participation in public debates. Questions of representation and self-representation, of visibility, pluralism and access have loomed large in this literature, with a clear concern for minority positions to be articulated, heard, read and seen in mass media circuits of various sorts. Ever since the role of mass media as the crucial context for public debate and opinionshaping in complex, modern democratic societies was pointed out by Jürgen Habermas and others (Habermas, 1969; Enzensberger, 1970), the existence of a plurality of mediated public spheres and their interrelationship has been a topic of much discussion (Negt and Kluge, 1993; Robbins, 1993; Calhoun, 1992).

What has remained relatively uncontested, however, is the basic agreement that the public character of mass media is essentially related to possibilities of discursive intervention - to possiblities of circulating mediated, 'textual' representations that will carry significance in public discourses (Warner, 2002b). High hopes have in this context been tied to the internet as a developing mediated arena that offers seemingly endless possibilities of articulating minority positions in a growing and potentially unlimited realm of virtual space. Public spheres, understood in this sense, are always spheres of discourse, and possibly of democratic representation and debate. This debate might not be as straightforward as Habermas saw it in his somewhat idealized account of the print-media based male bourgeois public sphere of $19^{\text {th }}$ century Germany, but there is a wide consensus that - as a normative idea, an ideological ruse, or factual, however compromised reality - media representations crucially influence our opinions and increasingly shape our political and cultural perceptions of the world, and thus also of contentious issues and the ways in which they might be resolved.

$1 \mathrm{I}$ use the term postmigrant here to refer to an increasing number of people who were born in the country of residence in the second, third etc. generation, but for whom diasporic or transnational affiliations created through family histories of migration still play a significant role in their lives. Neither the term migrant nor the concept of an ethnic minority can adequately describe these circumstances. 


\section{THE DECLINE OF MULTICULTURAL BROADCASTING IN GERMANY}

A very explicit contribution to public debates in Germany was intentionally created with the establishing of public-service multi- and intercultural broadcasting programmes in the 1990s. Radio stations like Radio MultiKulti or Funkhaus Europa and TV-formats like SchwarzRotBunt ${ }^{2}$ claimed to provide both visibility and a 'voice' to Germany's immigrant minorities, seeking to counter the absence of migrant and ethnic minority perspectives from mainstream mass media programming on television and radio. Racist attacks on asylum seekers and Turkish-German residents in the early 1990s had fuelled political demands for public-service programming that would not just give a voice to immigrant ethnic minorities, but also educate the 'native' majority population to increase tolerance and intercultural understanding. In line with their public-service mission, several of the federal-state-based broadcasting corporations cooperated both to service minorities in the interest of 'pluralism' and to educate majorities in terms of introducing them to what were deemed 'foreign cultures' (Kosnick, 2000).

However, several factors combined to eventually erode support for this type of multicultural programming. In the mid-1990s, a period which marked the apex of public-service multicultural broadcasting in Germany, commercial reasoning slowly began to battle with and come to dominate over the political arguments that had brought multicultural programming into existence. Most programmes could not boast the kinds of audience ratings that could have justified their continuation on the basis of commercial criteria. The effects of the introduction of private, commercial broadcasting in the 1980s (in what was then West Germany) put increasing pressure on public-service broadcasters to compete for audiences, while the transnationalization of broadcasting in the wake of digital satellite television partially undermined the argument that public-service corporations had to service immigrants as a minority population that was deprived of culturally specific or inclusive broadcasts. Whereas in the early decades of post-war labour migration to Germany, migrant audiences were dependably glued to the public-service radio programmes broadcast in different languages, in the course of the 1990s, their options had multiplied. As several quantitative studies of mass media usage in immigrant households showed, immigrants and their descendents had begun to make use of a broad range of transnational, national and local media sources, with satellite imports and commercial German television winning out over public-service offerings. The development of the internet has of course placed an even greater strain on this strategy of justification, as access to the apparently unlimited reception and production of public media representations now seems only a mouseclick away.

2 BlackRedMulti-Coloured, a wordplay drawing on the colours of the German national flag.

REMI 2010 (26) 1 pp. 37-55 
Another important factor that bode ill for the public-service offerings was the changing political climate in Germany. The political logic of multiculturalism which was based on a vision of immigrants representing distinct cultural communities that should be given a collective 'voice' and the chance to maintain their 'cultural identity' has come under increasing criticism, particularly in the wake of the moral panics surrounding the Muslim presence in Europe after Islamist terror attacks and the beginning of the so-called War on Terror. In its wake, a noticeable shift has taken place with regard to how immigrant 'difference' has come to be constructed and problematized. While ethno-national perspectives dominated during the period of multiculturalism, this has moved towards a religious-cultural construction of difference, with Islam taken to represent both a religion, a value system and a vision of sociopolitical order at odds with the political systems and values tied to an implicitly or explicitly 'Christian', allegedly tolerant 'West' (Bunzl, 2005). Such ideas were articulated not just by the right-wing political spectrum, but also by representatives of mainstream parties and supposedly 'critical' mass media sources, who have highlighted alleged integration failures and have blamed a 'lax' multiculturalism for the emergence of Islamist violence, youth delinquency and so-called 'honour killings'.

\section{Commercial alternatives: Metropol FM}

Public-service multicultural programming also faced increasing competition by migrant media broadcasters in the commercial domain, such as the Berlin-based radio station Metropol FM which broadcasts almost all of its programmes in Turkish ${ }^{3}$. Different from the similarly Berlin-based public-service radio station Radio MultiKulti, which used to offer one hour of Turkish programming on weekdays and was shut down in 2008, Metropol FM is clearly entertainment-oriented and scrupulously avoids any issues that are likely to polarize or antagonize its target audience. Issues such as the struggle for Kurdish independence in Turkey, the divide between Alevi and Sunni Muslims, or the conflict around religious education in Berlin schools are real concerns among the city's immigrant population from Turkey, but given their contested nature, the station seeks to keep them out as far as possible.

This might seem easy enough for a programming schedule that is almost exclusively dominated by music, but even music is likely to evoke contentious positions among immigrants from Turkey by often being aligned with particular political-cultural or religious positions. Various genres of Turkish Arabesk, classical Sanat Music, folk music and özgür (freedom) music are associated with different histories of conflict and nation-building in Turkey, histories that are remembered by

3 With the exception of German-language news bulletins that are mandated by the federal state media agency and are bought in from a news outlet in Munich. Ten years after its inception, Metropol FM can now also be received terrestrially in the cities of Stuttgart, Koblenz, Ludwigshafen, Mannheim, Mainz and Wiesbaden, all of them home to significant numbers of Turkish-German residents, as well as offering live-streaming via the internet at http://www.metropolfm.de/. The standardized programming fare allows to regionally insert locally relevant advertising addressing consumers in specific locations. 
and politically charged even among second- and third generation immigrants. Station representatives reasonably fear that any broadcast of such evocative music could be met with harsh reactions, enough to discredit the station's aim to provide an unobtrusive easy-listening option.

Interviewing the acting (German, non-immigrant) director of Metropol FM shortly after its broadcasts began in 1999, he told me that the station could not afford to alienate even the smallest part of its already relatively small target audience. He recounted numerous incidents in which representatives of various Turkish and Kurdish groups and organizations in the city had attempted to apply pressure on the station to take up particular issues or even just play particular kinds of music associated with their respective causes. Sticking to a music diet of relatively innocuous Turkish pop music, a genre that had emerged during the 1990s as a cross-generational easy-listening favourite in Turkey, the station strenuously resisted such attempts ${ }^{4}$.

What is more, great care was taken to hire personnel that was beyond doubt as far as political-religious leanings were concerned. Together with other friends I had made in the context of my own production work and research on Turkish and multicultural broadcasting in the city, I had responded to the station's advertisement in 1998 and applied for a job as part of the editorial team. I was invited for an interview but quickly told that my imperfect knowledge of Turkish did not sufficiently qualify me for the job. Instead, the station manager who carried out the interviews (and whom I had already interviewed on another occasion) took the opportunity to ask me about other candidates who were in the running, trying to find out whether I knew of any rumours or had evidence of their political leanings, given my knowledge of Turkishspeaking journalists in the city. While I did not volunteer such information, we had an interesting conversation about the possible pitfalls of hiring people 'known' in Turkish circles to represent particular controversial positions. Prior Turkish broadcasting initiatives in the city, he quite correctly observed, had almost always been motivated by the desire to intervene in conflictual political debates and thus to influence audience opinions. The Turkish television broadcasts on Berlin's widely available open access cable TV channel $O K B$ were legendary among immigrants for articulating 'extreme' right-wing, islamic or Kurdish-nationalist positions, and even public-service Radio MultiKulti's Turkish broadcasts had a reputation as having a high-brow, secularist agenda in tune with Kemalist ${ }^{5}$ elites in Turkey. Other local commercial television

4 There were instances, however, when news events did affect the programming schedule, as in the case of the severe earthquake that devastated the Turkish city of Izmit and its surroundings in August of 1999, just months after the station began to broadcast. Metropol FM reported extensively, changed its music schedule and launched a charity drive to help victims. The humanitarian catastrophy united its audience in shared grief and did not endanger the station's apolitical stance.

5 The founder of the Turkish Republic, Mustafa Kemal Atatürk, built a modern Turkish state on the principles of Turkic nationalism, secularism and 'pro-Western' cultural and social reforms. $\mathrm{He}$ is still revered in Turkey, particularly by the 'Kemalist' elites, though more critically appraised by the new Islamic elites that have gained increasing power in contemporary Turkish politics (Navaro-Yashin, 2002; Seufert, 1997). 
projects such as AYPA TV or TFD (Turkish TV Germany) had been discredited by being associated with Alevi ${ }^{6}$ or religious-nationalist causes respectively. Metropol $F M$ 's reason for seeking to avoid any association with political controversy - so crucial to the idea of a democratic public sphere - was plainly commercial, so as not to provoke any negative reactions among the target audience of Turkish-speaking Berlin residents.

As the station's director Felten told me, it was simply nonsensical to expect a commercial radio station to invite controversial debate. In fact, any sort of strong reaction to its programming had to be avoided, he said, even positive ones. "I get alarmed when somebody tells me they really love our music", he stated, "because radio is supposed to be a background medium". The desired response to Metropol's programming for him was one of benign toleration, turning on the radio as a nonirritating backdrop to daily activities such as driving to work, doing the dishes or having breakfast in the mornings. The minority orientation of the station had nothing to do with 'giving a voice' to a formerly marginalized immigrant group, it was simply a matter of identifying a niche market that could cater to the tastes of an as-yetunserviced consumer group. The public character of broadcasting was in his rendition no more than a convenient way of getting a product to a maximum range of consumers whose precise identities and numbers could not be exactly known.

\section{The decline of the public sphere?}

The story of Metropol FM seems to precisely bear out the fears that Jürgen Habermas had articulated with regard to the alleged 'decline of the public sphere'. The market logic that has come to dominate mass media production in Germany has meant that forms of debate and the shaping of public opinion in the interest of democratic will-formation are no longer a central concern of most mass media producers. This also holds true for the Turkish-language mass media production that is produced for and/or targets audiences in Germany. While just ten years ago, Turkish-language media projects with a socio-political or religious vision still flourished in a German media environment influenced by political commitments to a so-called multicultural society, the current situation is radically different. The plethora of amateur Islamic television programmes broadcast on open-access television channels in cities like Hamburg, Frankfurt and Berlin has been deliberately curbed by new regulations (Bentzin et al., 2007), and 'intercultural' radio programming in the public-service domain has either been abandoned (such as the internationally praised Berlin radio station Radio MultiKulti) or is under threat (such as the so-called Ausländerredaktion at the Hessischer Rundfunk in the federal state of Hessen). Smaller migrant media producers who once hoped to develop their socio-politically motivated broadcasting or print

6 Alevis constitute a Muslim minority in Turkey, where Sunni Islam dominates. Estimates put their numbers at up to 20 percent of the population in Turkey, with a similar share among the population that has migrated abroad (Kosnick, 2004). While the AYPA producers refused this identification, they were nevertheless widely seen as promoting Alevi causes.

REMI 2010 (26) 1 pp. 37-55 
projects into commercially viable ventures have not been able to establish themselves in the long run. Among them are the German-Turkish television project AYPA TV, the Turkish-language newspaper project 8.Gün, the Turkish-nationalist and religious Milli Görüş-friendly ${ }^{7}$ TFD and others. ${ }^{8}$

In light of these developments, one could quite justifiably come to lament the decline of mass-mediated public spheres that offer critical input by and for migrants. One could also, as has been done, point to the internet as a partial remedy, a major socio-technological transformation with profound cultural and social consequences that offer multifarious opportunities for public debate and opinion formation that involve both migrant and non-migrant populations across territorial boundaries (Deuze, 2006). There is certainly a need for studying the use of the internet and the production of content produced for various forms of internet publication by diasporic populations, migrants and their descendants.

For the purposes of this article, however, I want to remain chiefly with the 'traditional' mass media forms of television and radio broadcasting and ask how their public function could be rethought in light of urban publics. The argument I want to advance is that these 'mass' minority media have public functions beyond and apart from the hosting of debates in the interest of opinion-formation or the representation of minority identities; functions that require a closer look at the conceptualization of the public underlying much public-sphere theory.

\section{CONCEPTUALIZING THE PUBLIC}

One of the most interesting recent attempts to rethink the notion of the public has been produced by Michael Warner, who has explored the ambiguities underlying the concept in a number of influential articles and books. In a much-noted essay on 'publics and counterpublics', he posited that publics do not refer to pre-constituted social groups or communities, but come into being as a collective only through their participation in public spheres (Warner, 2002a). Historically contingent and contextdependent, but also simultaneously functionally intelligible as a potent idea across these contexts, publics exist by virtue of their imaginings, but are nevertheless anything but ficticious.

As others before him, Warner exposes the idea of a single, rational-discursive public sphere of democratic deliberation as an ideological fiction, but more radically than others proceeds to identify multiple counter-public formations and imaginations that are associated with minorities - in his case, particularly sexual minorities. While the public as a radically democratic, self-organized and accessible forum of opinion-

7 Milli Görüşs started as the foreign wing of the new Islamist movement in Turkey associated with figures such as Necmettin Erbakan. It is one of the most influential nationalist-islamist organizations in Western Europe, while its political links to Turkish parties and stance towards 'host societies' are also internally disputed.

8 The Kurdish-nationalist diasporic television channel Roj-TV is an exception (Kosnick, 2008). 
formation and political agency might have always been an ideological ruse rather than actually existing fact (ibid.), the existence of publics as particular kinds of unstable and open contexts of stranger sociability certainly is not. Central to Warner's understanding of publics is that they are made up of an indefinite number of strangers who are brought together as witnesses of an event, as addressees of a reflexively circulating discourse. His argument is that "...the notion of a public enables a reflexivity in the circulation of texts among strangers who become, by virtue of their reflexively circulating discourse, a social entity" (Warner, 2002b: 11-12). However, to function as a public, this entity needs to exist not just in itself but also for itself:

"The idea of a public is motivating, not simply instrumental. It is constitutive of a social imaginary. The manner in which it is understood by participants is therefore not merely epiphenomenal, not mere variation on a form whose essence can be grasped independently." (ibid., pp.12)

Crucial to both the idea and the functioning of publics is thus the imagining of a shared engagement, the knowledge of unknown others being similarly, deliberately and simultaneously involved in a meaningful event.

\section{Imagined publics}

When Benedict Anderson in his book 'Imagined Communities' famously discussed the cultural roots of national consciousness by refering to the "mass ceremony" of imagining involved in the simultaneous reading of the morning newpaper edition across national territory (Anderson, 1991: 35), he was not in fact interested in the contributions of such acts to forms of democratic debate. What concerned him was the implicit invocation of an imagined 'community' of co-nationals for every individual reader in the act of reading:

"...each communicant is well aware that the ceremony he [sic] performs is being replicated simultaneously by thousands (or millions) of others of whose existence he is confident, yet of whose identity he has not the slightest notion."

(ibid., pp.35)

Anderson's interest lay, of course, with the social imaginings that produce a national consciousness, but he in fact thereby also highlighted the public function of mass media - their forms of address directed towards an, at the individual level, unspecified group of recipients, the expectation of all recipients that individually unspecified, "strange"9 others share in this reception - as a central element of social imagining for any public media audience.

The naturalized, taken-for-granted invocations of a 'national community' are obviously compromised in a media age where mass media have proliferated and do not attempt or cannot expect to address 'nationwide' audiences. Neither will each reader be

9 Strangers not in Zygmunt Bauman's sense of the term, where they represent those who do not fit the ordering "zeal" of the state, the hated and feared outsiders (Bauman, 1995). 
(and have been) able to feel him- or herself securely addressed as a fellow national. Minorities who did or do not conform to the normative expectations tied to national cultural citizenship will have (had) to negotiate a different relationship to the imagined national public audience.

The pressure to confront such exclusionary imaginings of national community has potentially eased with the proliferation of media representations made possible by new technologies, cross-border dissemination and production, and the commercialization of broadcasting that has transformed the conditions for cultural citizenship. Nowadays, both the intended audience constructed as an addressee in contemporary mass media representations and the actual audiences engaging with them do not easily allow us to assume that the social imaginings involved refer to the nation, nor necessarily to other forms of allegedly homogeneous community. What they do allow for is the continued assumption that media representations involve social imaginaries of different kinds of publics, though not necessarily in the interest of public-democratic debate.

\section{Metropol FM and the imagining of urban publics}

Coming back to Metropol FM's function as a Turkish-language radio station targeting Turkish speakers in the city of Berlin, its existence as a commercial project that deliberately avoids deliberation on controversial issues does not indicate the lack of a public function. While it does not fulfill the criteria set out by Habermas and others to function as a public or even counter-public sphere in which there needs to be room for discursive contestation, it does importantly contribute to the formation of public imaginings.

Talking to young Berlin residents with migrant backgrounds from Turkey about their media consumption habits a few years after the station began its broadcasts ${ }^{10}$, many of them emphasized the importance of Metropol FM in providing a particular kind of soundscape for their public urban lives. Instead of having to play Turkish music tapes or CDs on their car stereos, Metropol FM added this music to the range of mass-mediated, publicly available soundscapes that allow their audiences to feel part of the here and now of an imagined public of urban listeners. Young men in particular mentioned the joy they felt when Turkish sounds were emanating from open car windows, their own or those of strangers passing by. One informant in his late twenties who had grown up in Berlin but travelled a lot due to his occupation described the importance of Metropol FM in terms of home: "When I'm driving back towards Berlin in my car there is this moment when you start catching the radio signal at the outskirts of the city. That's when I know that I've actually come home, there is that feeling of elation."

10 In the context of a small door-to-door survey among Turkish households in the district of Kreuzberg, and in casual conversations with young people involved in the Turkish club scene in the city. 
In the case of these young audiences, they tended to value Metropol FM's form of address a lot more than the rather high-brow and educational broadcasting approach of Radio MultiKulti, whose Turkish-language programming was in conversations often deemed "too intellectual" and somewhat heavy-handed in its educational mission. The fact that Metropol FM listeners did not have to tune in at particular times of the day or week to catch Turkish programming contributed to its importance in giving an audible presence to public Turkish life in the city. To put a slight twist on Anderson, its listeners were thus "...continually reassured that the imagined world is ... [audibly] rooted in everyday life" (1991: 35-36). Metropol FM in this sense provides a public soundscape that contexualizes daily routines, and positions Turkish-speaking listeners in a specific urban space to which they are assumed to belong. "We are simply a german radio station in Turkish," the acting executive director of the station said to the German press on the occasion of Metropol FM's tenth birthday party. ${ }^{11}$

The very indifference of the station towards controversial topics, its standardized fare of music, advertisements and news summaries that mirrors that of other commercial radio stations in the city and elsewhere, holds out a promise that Radio MultiKulti was never able to fulfill: to construct the Turkish presence in Berlin as ordinary (Robins, 2000), as part of the city and its rhythms, as part of a population of city residents with a migration history, many of whom prefer not to be continuously addressed as a special political interest group. At Radio MultiKulti, ordinariness in this sense was never really an option: ethnic minority listeners were continously reminded of their burden of ethno-cultural representation in programmes designed to highlight the 'ethnic' angle on every issue (Kosnick, 2007). Ethnic minority listeners were addressed as part of the city, but as a culturally distinct part expected to provide culturally specific perspectives on urban life.

\section{Consumer publics}

The kind of cultural citizenship that was constructed at Radio MultiKulti explicitly related to the "right to know and to speak" (Miller, 2007), expanding the public-service mission of education and information to include immigrants as culturally specific audience 'communities'. Metropol FM's programmes instead imply a different kind of cultural citizenship by interpellating its audience simultaneously as city residents and as consumers, consumers whose claim to social participation is importantly mediated by commodities. Attracting advertising is not just key to the economic survival of the station, advertisements also form a crucial part of its broadcasting appeal that holds out the promise of participating in popular consumer culture. This is of course anything but a special feature of Metropol FM - it is rather a hallmark of cultural industries in late capitalist social formations where social relations are economically and symbolically mediated through markets. As Toby Miller put it, "Clearly, with consumers targeted by a culture-driven economy, their identities come to be points of sociopolitical and commercial organization." (Miller, 2007: 9)

11 Director Tamer Ergün as quoted in the Berlin daily Tagesspiegel on 22/06/09.

REMI 2010 (26) 1 pp. 37-55 
It is ironic, yet befitting the trend towards a redistribution of wealth in many highly industrialized countries that the buying power of former labour migrants from Turkey and their descendants has been in decline over the past decade. According to surveys carried out by the Centre for Turkey Studies, already in 2005, almost one third of Turkish households in Germany were living below the official poverty line. Another thirty-five percent were living dangerously close above it. ${ }^{12}$ During the very same period, however, so-called ethno-marketing has taken off in Germany, with marketing agencies such as TürkNet Media or KOM Media emphasizing the untapped consumer potential of Turks in the country, and large companies (e.g. Telekom, Volkswagen, Deutsche Bank and others) developing special advertising campaigns and placements to reach out to Turkish-speaking customers. ${ }^{13}$

The argumentative strategies ethno-marketing agencies use in their interaction with corporate actors are not that far removed from those used by representatives of Turkish migrant organizations vis-à-vis German state institutions: minority citizens/ customers deserve special recognition as they make special contributions to society/ consumer markets. The argument of tapping into and recognizing the diversity of niche markets, however, seems to be winning out over the 'politics of recognition' (Taylor, 1992) that for two decades dominated German integration debates and public-service media policies towards immigrant minorities. Recognition is now linked to diverse consumer preferences rather than to diverse ethnic minority 'communities' constructed as corporate political actors. Despite the decline in buying power, the general trend towards niche marketing and the overall growth of the postmigrant population with roots in Turkey still renders Turkish Germans an interesting target group; interesting enough to fuel and subsidize a range of commercial media projects from Metropol FM to internet platforms such as turkdunya.de or vaybee.de, and the transnational broadcasting activities of Turkey-based television channels such as Kanal D or ATV. What unites all of these projects despite being based on quite different media technologies is their low-budget approach and their targeting of fragmented audience segments, with production costs significantly lower than those of their old-school public-service or state-sponsored radio and television equivalents, and profits that can be made from relatively small audiences.

Public-service broadcasters in Germany have since the introduction of commercial broadcasting in the 1980s faced increasing market pressures despite their different funding base. Ratings have come to be understood as a kind of popular plebiscite that can be linked not only to advertising revenues but also to the dwindling legitimacy of spending public money on relatively high-cost productions. Migrantoriented public-service programming like Radio MultiKulti, with its high word-content and ambitious profile, have slowly but surely lost the political support that had brought them into existence at a time of right-wing anti-immigrant violence and concerns over

12 According to a study carried out by the Centre for Turkey Studies, www.mgffi.nrw.de/pdf/integration/NRW-Bericht_2006.pdf, last accessed 20/04/09.

13 http://www.welt.de/wirtschaft/article1597874/Warum_deutsche_Firmen_auf_Tuerkisch_werben.html, last accessed 20/04/09. 
integration failures in the newly united Germany of the early 1990s. The formerly dominant multiculturalist paradigms that held the state responsible for giving recognition and rights to ethno-cultural communities have given way to renewed calls for a German 'Leitkultur' (leading culture) ${ }^{14}$ in light of alleged integration failures and fears regarding Islamist extremism and potential terror attacks.

Simultaneously, new conceptions of diversity have gained prominence in popular cultural discourses, partly aided by academic celebrations of cultural hybridity and flows, which are much more in tune with a marketization of meaning production that links cultural differences to an expanded logic of capitalist economic utilization (Nghi Ha, 2005). 'Hybridization' promises an endless supply of cultural differences that can be turned into new consumer products (Holert, 1998; Terkessidis, 1999). These cultural differences are no longer the basis for forms of political recognition that need a stable social referent, i.e. immigrant groups addressed as ethnic minority communities. Instead, they are linked to changing consumption proclivities, some of which might have an ethno-cultural base or can be linked to specific dimensions of transnational lifestyles, such as cellphone-flatrates for calls to Turkey or cable-TV package deals that deliver an assortment of channels from Turkey via German cable networks.

\section{CITIES AND PUBLICS}

To point out these developments is not simply to reiterate a form of cultural pessimism that has been well-rehearsed many decades ago by the Frankfurt School theorists (Adorno and Horkheimer, 1972). It is crucial to understand the new marketdriven valorizations of diversity and dynamics of broadcasting in order to make sense of the changing politics of representation in relation to migrant and ethnic minority media. While the developments described above show that the latter have been caught up in and shaped by forces of commercialization and deregulation that threaten their discursive-political function as arenas of public deliberation, it is worth coming back to the critique of the public sphere concept in order to examine how public imaginings and public formations are shaped by them beyond the story of decline. For even though the shift towards profit-driven mass media production has decreased the potential for mass media to function as arenas of public deliberation, they might still provide an impetus for significant publics in a different sense of the term.

The example of Metropol FM showed that the creation of a public soundscape addressing the Turkish-speaking population of Berlin contributed to rendering their presence both public and ordinary, allowing listeners to be addressed as part of an imagined minority public anywhere and anytime, as part of the urban fabric. The sense of belonging among audiences relates not necessarily to feeling part of an ethnic minority community, but rather to feeling part of the city as an essentially public social location, one in which an ethnic minority can be imagined not as a community but as an urban public.

14 See Bassam Tibi, Leitkultur als Wertekonsens - Bilanz einer missglückten deutschen Debatte, In: Aus Politik und Zeitgeschehen (Das Parlament), B 1-2/2001, S. 23-26.

REMI 2010 (26) 1 pp. 37-55 
The attraction of cities as places to live resides not only in the availability of jobs, of good infrastructures and institutionalized cultural offerings such as museums etc. Their appeal is also associated with the co-presence of strangers and the possibilities for encounter or anonymity that go along with it. While their presence might be experienced as a nuisance during morning rush-hours, it is also actively sought out in practices of 'going out' that fuel urban nightlife economies and scenes (Blum 2003). The experience of urban diversities and spectacles is most often linked to the co-presence of unknown others, with whom one shares not simply an urban residence status but also a deliberate interest in being 'out in public'. ${ }^{15}$ This at first sight quite different understanding of public formations is important to consider when trying to link the imaginings of mass-mediated publics to the experience of urban publics that involve possibilities of face-to-face encounters.

The kind of sociability involved in publics is one that entails a necessary degree of openness with regard to the number and identity of the participants involved. The term 'public' denotes accessibility and an element of voluntary association. Public arenas are those that have no pre-defined participation, and they bring together potential strangers who might share particular categorical belongings and expectations with regard to commonalities and norms of engagement, but will not usually know each other personally. This social imaginary of stranger-relationality that is central to publics can but must not be discursively grounded in the sense of being oriented towards debate.

While Michael Warner's interest in publics remains tied to possibilities of discursive transformation through texts, he also hints at a wider, more basic understanding of publics, one that defines publics as a collectivity of persons whose primary interrelation is constituted via participation in an event - events that are not necessarily dominated by circulating texts in a discursive arena. Warner's own interest is in the 'poetic-expressive' aspects of (counter)public world-making, thereby already partly dislodging "the privilege assigned to critical-rational discourse in dominant publics" (Deem, 2002: 445). Warner himself questions "...to what degree the text model, though formative for the modern public, might be increasingly archaic" (Warner, 2002b: 16), yet eventually remains with the idea that publics are essentially intertextual. The focus on the circulation of language keeps him from considering the possibility of publics whose interrelation is not primarily forged through the engagement with circulating 'texts', but through a shared participation in events that might also involve face-to-face encounters between strangers.

\section{PUBLIC SCENES}

The scene described at the beginning of this article gives an indication of how commercial media production can help to produce publics that involve face-to-face stranger relationality in urban space. When the streets of Berlin's Kreuzberg district

15 The experience of diversity of cities is in this respect anything but witnessing a mosaic of ethno-cultural communities that each celebrate and guard their cultural heritage. 
filled with Fenerbahçe football club supporters while at the same time, the fans of the German cup final winner Nürnberg celebrated elsewhere in the city, nationally and transnationally mass-mediated events simultaneously left their mark upon the urban fabric. The celebratory outdoor gatherings that followed the two title decisions in Berlin created public scenes in the double sense both of temporary, ephemeral social formations and of somewhat transgressive, theatrical disruptions of the everyday street routines that mark both locations.

The Fenerbahçe fans in particular had not been physically present at the game that interested them, yet the considerable geographical distance that separated them from the actual location of the game did not prevent them from celebrating as if they had been present. This is not just due to them having had access to the television transmission of the game from Turkey, and thus having been addressed as part of a territorially unbound Turkish audience. Significantly, it also had to do with their reasonable expectation that in the district of Kreuzberg, they could expect for their celebrations to be understood and joined by others, turning their expressions of joy into a public performance that partially dissolved the borders between performers and audiences. The fleeting transformation of urban public space that was effected relied not just on the dispersed existence of transnational television audiences, but also on participants' relationship to an area of the city to which they could stake a public claim. The fact that scores of mostly young Fenerbahçe fans could leave their TV sets and pour out on city streets to applaud each other and turn the win into a public celebration tells us something about the public socialities of (post)migrant urban life that usually go unnoticed.

Social science research on contemporary (post)migrants in Western European cities tends to put emphasis on relatively enduring social formations and structures, such as residential segregation patterns, ethnic niche economies, labour market statistics, educational achievements and the like (Alba, 2005; Crul and Vermeulen, 2003; Johnston et al., 2002; Miller, 2006; Pütz, 2004; Simon, 1998; Vermeulen and Perlman, 2000). Much less attention is paid to the variety of social practices and identifications that involve these mostly urban residents in much more fleeting social formations, formations that have been described as central to contemporary urban life (Blum, 2002), yet not for ethnic minorities. Migrant and ethnic minority publics have been explored in relation to media use and production, but almost never in relation to urban environments. Yet, as media technologies and practices cross national boundaries and help to foster geographically dispersed audiences, they also affect the practices and imaginings of community and sociality in face-to-face urban settings. What is more, these settings are not simply home to ethnic or migrant communities, the placeholder concept mobilized to stand in for any social formation that refers to ethnic minorities or immigrants as social groups (Alleyne, 2002). (Post)migrants are also involved in social practices and social imaginings that involve urban publics as temporary formations of stranger relationality. 


\section{CONCLUSION: PUBLICS AND SPACES}

The scenes described involve (post)migrants in deliberate, temporary and public engagements with strangers in which a shared concern or interest is important. But this kind of "stranger relationality" (Warner, 2002a: 57) is not the passive witnessing and observing of a spectacle ${ }^{16}$, nor is it the public dialogical context that gives rise to hopes of democratic will-formation. The participatory face-to-face context which it offers is instead one that the urban researcher Alan Blum describes as practices of seeing and being seen, in fleeting performative activities that involve participants in acts of mutual recognition rather than just voyeurism (Blum, 2002: 14). The social dimensions of such urban publics do not resemble the collectivity of community, even if they might involve the imagining of a sort of community, as for example that of a transnationally celebrating fan collective. The forms of actual social engagement and bonds between participants are much more transitory, involve less obligation and have more porous boundaries than the concept of community implies, ever since German sociologist Ferdinand Tönnies' influentially defined it in his dichotomization between community and society (Tönnies, 1979 [1887]). As in any public social formation, they thrive on the co-presence of strangers - a presence that is anything but accidental and deliberately sought out by participants. What rendered the football celebrations public was not only that they took place on public streets, but that they involved a conscious, voluntary stranger-relationality centered around a shared activity. It was not simply the location of this activity and its participants that rendered it public, rather, the kinds of social encounters with strangers that participants engaged in transformed the location into a public space.

The question of the relationship between publics and geographically locatable space has not been central to the debates on public spheres that developed out of the Habermasian account of decline. With the historically assumed shift from the quintessentially urban scene of the agora at the centre of the ancient Greek city state site for the powerful myth of origin for the proto-democratic public sphere - to forms of mass-mediated public deliberation, the spatial dimensions of public participation have received little attention. Michael Warner has claimed for text-based publics that “...space and physical presence do not make much difference" (Warner, 2002a: 53), and has proceeded to regard publics as "the social space created by the reflexive circulation of discourse" (ibid.: 62). This "quasi-metaphorical usage of space" (Wittenberg, 2002: 426) that dominates in the works of Warner and other public sphere theorists whose main interest focuses on discursive publics effectively elides the question of how public stranger sociality is tied to the use and production of concrete spaces.

It is a crucial question to ask even for discourse-focused publics, though, as soon as we recognize that any circulation of discourse relies upon material infrastructures and locations that are organized by dimensions other than discourse itself. To

16 By which I do not wish to imply that the collective witnessing of spectacles does not have multiple productive dimensions for audiences. 
give a concrete example related to migrant media production, the continued broadcasting of Kurdish-nationalist satellite TV channels based in Western Europe has been based upon the diasporic dispersal of Kurdish-nationalist activists across different national-territorial spaces, despite the efforts of the Turkish government to suppress it. Shifting studio locations, transponder rentals and license permits between these spaces, broadcasters were able to repeatedly escape the pressures exerted by successive Turkish governments to shut down their operations. National-territorial space was not rendered irrelevant through their satellite broadcasting, but instead tactically used to sustain continued programming (Kosnick, 2008).

If we shift our attention from questions of ethnic minority representation in mediated public discourses to those of minority participation in different kinds of publics that involve face-to-face interaction, it might simultaneously allow us to move from issues of semiotic 'content' to issues of sociality and urban space, and to focus on phenomena of urban publics that tend to go unnoticed in current research on ethnic minorities. In relation to urban space, then, it is important to recognize that the participation in urban publics is a significant form of place-making through which city residents both stake symbolic claims to the city and shape the urban fabric.

Participating in the fleeting creation of urban public space as in the case of the Fenerbahçe celebrations might seem a negligible act and event - after all, it did not have any noticable effect upon household incomes, educational degrees, residence patterns or labour market opportunities. Neither can it be claimed to have had any measurable impact on minority identity formation, given that Fenerbahçe fans would have been able to articulate the same sense of allegiance if interviewed in their livingrooms after the match. The fact, however, that ethnic minority viewers were able to celebrate the win of their team in a public context on the streets of Berlin tells us something about their ability to participate in quintessentially urban forms of public stranger-sociality and thus to experience the city neither as a place of community nor of alienation, but as a space of public belonging.

The stranger-sociability involved her differs markedly from the conceptions of the stranger as a figure excluded from social, cultural and political belonging, as Bauman and others have described it (Bauman, 1995). It is worth noting that strangeness does not always have to equal social exclusion and elicit fear or hate. Bauman's stranger as the by-product of social ordering and identity-building in modern states can only evoke attempts at cultural or physical annihilation, via expulsion, assimilation or murder. Yet, the consideration of public forms of deliberate sociability shows strangerrelationality to possibly be desirable and joyful, with the potential to involve participants in manifold temporary public formations that involve different kinds of social imaginaries. This is particularly relevant for ethnic and other kinds of minorities, whose best hope seemed to lie in loosing their status as strangers without having to dissimulate. Realizing that stranger-relationality is an essential and desirable part of publics as imagined yet actualized social formations that are central to the contemporary historical moment, we can study the participation of ethnic minorities and (post)migrants in different kinds of publics as a significant phenomenon beyond the context of media spheres. 


\section{References}

ADORNO Theodor W. and HORKHEIMER Max (1972) The culture industry: Enlightenment as mass deception in T.W. Adorno and M. Horkheimer (ed.) The Dialectic of Enlightenment, New York, Herder and Herder, pp. 120-167.

ALBA Richard (2005) Bright vs. Blurred Boundaries: Second-Generation Assimilation and Exclusion in France, Germany, and the United States, Ethnic and Racial Studies, 28(1), pp. 20-49.

ALLEYNE Bryan (2002) An idea of Community and its Discontents: Towards a more Reflexive Sense of Belonging in Multicultural Britain, Ethnic and Racial Studies, 25(4), pp. 607-627.

ANDERSON Benedict (1991) Imagined Communities: Reflections on the Origin and Spread of Nationalism, London, Verso.

BAUMAN Zygmunt (1995) Making and Unmaking of Strangers, Thesis Eleven, 43, pp. 1-16.

BECKER Jörg (1998) Multiculturalism in German Broadcasting, Media Development (3), pp. 812.

BENTZIN Anke et al. (eds.) (2007) Islam auf Sendung, pp.Islamische Fernsehsendungen im Offenen Kanal, Berlin, Dagyeli.

BLUM Alan (2002) Scenes, Public (22/23), pp. 7-35.

BLUM Alan (2003) The Imaginative Structure of the City, Montreal, McGill University Press.

BUNZL Matti (2005) Between Anti-Semitism and Islamophobia: Some Thoughts on the New Europe, American Ethnologist, 32(4), pp. 499-508.

CALHOUN Craig (ed.) (1992) Habermas and the Public Sphere, Cambridge, Mass., MIT Press.

CRUL Maurice and VERMEULEN Hans (2003) The Second Generation in Europe, The International Migration Review, 37(4), pp. 965-986.

DEEM Melissa (2002) Stranger Sociability, Public Hope, and the Limits of Political Transformation, Quarterly Journal of Speech, 88(4), pp. 444-454.

DEUZE Mark (2006) Ethnic Media, Community Media and Participatory Culture, Journalism, 7(3), pp. 262-280.

ENZENSBERGER Hans Magnus (1970) Baukasten zu einer Medientheorie, Kursbuch Medienkultur pp. 264-278.

FRASER Nancy (1992) Rethinking the Public Sphere: a Contribution to the Critique of actually existing Democracy in C. Calhoun (ed.), Habermas and the Public Sphere, Cambridge, Mass., MIT Press, pp. 109-142.

GEORGIOU Myria (2006), Diaspora, Identity and the Media, Cresskill, NJ, Hampton Press.

HABERMAS Jürgen (1969), Strukturwandel der Öffentlichkeit. Untersuchungen zu einer Kategorie der bürgerlichen Gesellschaft, Neuwied, Luchterhand.

HOLERT Tom (1998) Mischkalkulationen und Gesichter der Zukunft in R. Mayer and M. Terkessidis (ed.) Globalkolorit: Multikulturalismus und Populärkultur, St. Andrä/ Wördern, Hannibal Verlag, pp. 25-39.

HUSBAND Charles (ed.) (1994) A Richer Vision: The Development of Ethnic Minority Media in Western Democracies, Paris, UNESCO.

JOHNSTON Ron et al. (2002) The Ethnic Geography of EthniCities: The 'American model' and Residential Concentration in London, Ethnicities, 2(2), pp. 209-235.

KOSNICK Kira (2000) Building Bridges. Media for Migrants and the Public-Service Mission in Germany, European Journal of Cultural Studies, 3(3), pp. 321-344.

KOSNICK Kira (2004) 'Speaking in One's Own Voice': Representational Strategies of Alevi Turkish Migrants on Open-Access Television in Berlin, Journal of Ethnic and Migration Studies, 30(5), pp. 979-994.

KOSNICK Kira (2007) Migrant Media: Turkish Broadcasting and Multicultural Politics in Berlin, Bloomington, Indiana University Press. 
KOSNICK Kira (2008) Exit and Voice Revisited: the Challenge of Migrant Media, Working Papers Forschungsgruppe Transnationalisierung, Goethe University Frankfurt.

MILLER Mark J. (2006) Opportunities and Challenges for Migrant and Migrant-Background Youth in Developed Countries, New York.

MILLER Toby (2007) Cultural citizenship. Cosmopolitanism, consumerism, and television in a neoliberal age, Philadelphia, Temple University Press.

NAVARO-YASHIN Yael (2002) Faces of the State. Secularism and Public Life in Turkey, Princeton, Princeton University Press.

NEGT Oskar and KLUGE Alexander (1993) Public Sphere and Experience: Toward an Analysis of the Bourgeois and Proletarian Public Sphere, Minneapolis and London, University of Minnesota Press.

NGHI HA KIEN (2005) Hype um Hybridität. Kultureller Differenzkonsum und postmoderne Verwertungstechniken im Spätkapitalismus, Bielefeld, transcript.

PÜTZ Robert (2004) Transkulturalität als Praxis. Unternehmer türkischer Herkunft in Berlin, Bielefeld, transcript.

RIGGINS Stephen H. (ed.) (1992) Ethnic Minority Media: An International Perspective, Newbury Park, Sage.

RIGONI Isabelle (2002) Turkish and Kurdish Media Production in Europe: A Comprehensive Overview, pp. 1-24.

http://www.lse.ac.uk/collections/EMTEL/Minorities/papers/turkishkurdimedia.pdf (accessed 22/02/2006)

ROBBINS Bruce (ed.) (1993) The Phantom Public Sphere, Minneapolis, University of Minnesota Press.

ROBINS Kevin (2000) Turkish (Television) Culture is Ordinary, European Journal of Cultural Studies, 3(3), pp. 291-295.

SEUFERT Günther (1997) Politischer Islam in der Türkei: Islamismus als symbolische Repräsentation einer sich modernisierenden Muslimischen Gesellschaft, Istanbul, Franz Steiner Verlag.

SIAPERA Eugenia (2005) Minority Activism on the Web: Between Deliberative Democracy and Multiculturalism, Journal of Ethnic and Migration Research, 31(3), pp. 499-519.

SIMON Patrick (1998) Ghettos, Immigrants, and Integration: The French Dilemma, Netherlands Journal of Housing and the Built Environment, 13(1), pp. 41-61.

SREBERNY Annabelle (2001) The Role of the Media in the Cultural Practices of Diasporic Communities in T. Bennett (ed.), Differing Diversities: Transversal Study on the Theme of Cultural Policy and Cultural Diversity, Strasbourg, Council of Europe Publishing, pp. 155167.

TAYLOR Charles (1992) Multiculturalism and 'The Politics of Recognition', Princeton, Princeton University Press.

TERKESSIDIS Mark (1999) Globale Kultur in Deutschland - oder: Wie unterdrückte Frauen und Kriminelle die Hybridität retten in Hepp A. and WinTer R. (ed.), Kultur - Medien - Macht. Cultural Studies und Medienanalyse, Münster, VS Verlag, pp. 237-252.

TÖNNIES Ferdinand (1979 (1887)), Gemeinschaft und Gesellschaft. Grundbegriffe der reinen Soziologie, Darmstadt, Wissenschaftliche Buchgesellschaft.

VERMEULEN Hans and PERLMANN Joel (2000) Immigrants, Schooling and Social Mobility: Does Culture Make a Difference?, Basingstoke, Macmillan.

WARNER Michael (2002a) Publics and counterpublics, New York, NY; Cambridge, Mass., Zone Books MIT Press.

WARNER Michael (2002b) Publics and Counterpublics, Public Culture, 14(1), pp. 49-90.

WITTENBERG David (2002) Going out in Public: Visibility and Anonymity in Michael Warner's 'Publics and Counterpublics', Quarterly Journal of Speech, 88(4), pp. 426-433. 


\title{
Les publics migrants : medias de masse et relations d'altérité dans l'espace urbain
}

\author{
Kira KOSNICK
}

En Allemagne, le développement de chaînes ethniques destinées à représenter immigrants et minorités, peut être aisément lu comme une histoire en déclin. En reconsidérant le débat discursif qui a marqué les principales réflexions menées sur la représentation des minorités dans la sphère publique, cet article propose une réévaluation de la notion de public dans le but de souligner les différents aspects de la construction de l'espace urbain et des imaginaires sociaux produits par les paysages médiatiques (mediascapes) turco-allemands.

\section{Migrant Publics: Mass Media and Stranger-Relationality in Urban Space}

\section{Kira KOSNICK}

The development of ethnic minority broadcasting in Germany that aims to give a voice to immigrants and minorities can easily be read as a story of decline. Challenging the focus on discursive deliberation that has marked major debates on minority representation and the public sphere, this article suggests a reconceptualization of the concept of the public in order to highlight different aspects of urban space-making and social imaginaries that are shaped by contemporary Turkish-German mediascapes.

\section{Públicos migrantes: los medios de comunicación de masas y la relación al Otro en el espacio urbano}

\section{Kira KOSNICK}

El desarrollo de las emisoras de los grupos de minorías étnicas en Alemania que tiene como propósito darle una voz a los inmigrantes y grupos minoritarios, fácilmente se puede entender cómo una historia en declive. Retando el enfoque de la deliberación discursiva que ha marcado los debates más importantes sobre la representación de minorías y la esfera pública, este ensayo/ trabajo/artículo sugiere una reconcepttualización del concepto de lo público para enfatizar los diferentes aspectos de cómo se crea el espacio urbano y los imaginarios sociales que han sido moldeados por "mediaescapes" étnicas contemporáneas. 